Article

\title{
Experts' Perceptions on the Particulate Matter Reduction Effects of Green Open Space
}

\author{
Suyeon Kim ${ }^{1}$, Seokjun Han ${ }^{2}$, Sang-Woo Lee ${ }^{1}$ (i) and Kyungjin An ${ }^{1, * \mathbb{C}}$ \\ 1 Department of Forestry and Landscape Architecture, Konkuk University, Seoul 05029, Korea \\ 2 Research Department, High Data, Seoul 05854, Korea \\ * Correspondence: dorian@konkuk.ac.kr; Tel.: +82-2-450-0444
}

Received: 19 August 2019; Accepted: 3 September 2019; Published: 4 September 2019

check for updates

\begin{abstract}
With recent declines in air quality, the significance of urban green spaces and their ecological functions have rapidly increased, especially with regard to the reduction of particulate matter. Various investigations regarding particle reduction in urban green spaces have been conducted; however, specific guidelines to establish empirical data for green spaces and to inform related policies are still lacking. Thus, this study aims to categorize experts' perceptions of green spaces through Q-methodology and to identify ways to form a consensus, establish policies in the design and construction process, ultimately aiming to enhance particle reduction effects in urban green spaces. As a result, experts' perceptions were classified into three categories: 'active support,' 'skeptical,' and 'passive support' groups. Experts' opinions on the particle reduction effects of urban green areas are overarchingly agreed upon; however, the priorities involved and methods used in augmenting green space integration require further analysis and mediation. Additionally, further empirical evidence should be accumulated on the particulate matter reduction effects of urban green areas, including the quantification of particle concentration reduction in urban green spaces and considerations for policy establishment in design and construction.
\end{abstract}

Keywords: air pollution; air pollution policy; particulate matter; urban forest; Q-method

\section{Introduction}

Currently, urban green areas are popular for the ecosystem services they offer, such as reducing flooding and improving air quality [1-4]. Recently, with the worsening of air pollution, interest in the ecological functions of urban green areas, in particular, the function of reducing particulate matter $\mathrm{PM}_{10}$ and $\mathrm{PM}_{2.5}$, has been rapidly increasing. Particulate matter (PM) are comprised of minuscule liquid or solid matter floating in the air [5,6]. PM can be created both naturally or artificially, and damagingly impact both the environment and human health [7]. In many Asian cities, because of air pollution from rapid industrialization and urbanization, PM pose a major environmental challenge. Ambient PM are a main public health issue in cities such as Seoul [8,9]; the latest related epidemiological research described a high correlation between PM concentrations and increased inpatients for lung and circulatory diseases [10-12]. Not only have PM become a serious health and social issue, but they also have had an economic impact; in South Korea, production activities are limited by PM, with an estimated economic cost of approximately $0.2 \%$ (3.3 billion dollars) of the GDP (Gross Domestic Product) [13].

As the PM problem has emerged as a serious social issue, research on the air pollution decontamination function of urban green areas has increased [6]. Several efforts have attempted to decrease the air concentration level not only of $\mathrm{PM}_{10}$ but also of $\mathrm{PM}_{2.5}[5,14-16]$. There are four major research areas in particulate matter reduction related to forestry and landscape architecture: 1) PM adsorption effects and abatement efficiency by species [15,17-19]; 2) PM reduction effect by buffered 
greenery such as roadside trees and roadside green buffer zones $[6,20,21]$; 3) PM reduction effects using greening techniques such as indoor landscaping, rooftop greening, and wall greening [22,23]; and 4) PM reduction effects from urban forests and green spaces by planting types and spatial structures [6,24-27]. Studies in each of these four domains have demonstrated the effects of trees and green areas on PM reduction. However, most of these studies have been conducted with a specific species or under specific conditions; more realistic or varied types of urban green spaces have been largely neglected $[16,28]$.

Since urban green spaces are also intended to reduce some of the ill-effects of climate change, e.g., the urban heat island effect, increased floods, and increased droughts, most countries regard urban green spaces as important in city and structural planning [1,29]. In response to the recently apparent utility of urban green space in reducing PM, state and local governments are actively preparing urban green area creation policies to enhance their ecological functions.

However, as the research and empirical data needed to inform such policies remains relatively insufficient, the perception of experts involved in policy development or design and construction can significantly enhance the political effectiveness of green space creation. Therefore, this study aims to examine and categorize the perceptions of green spaces from experts who establish, design, and construct urban green spaces and the related policies. Additionally, methods to form a consensus and improve awareness on the PM reduction functions of urban green spaces are investigated via surveys. This is intended to inform policy establishment related to urban green spaces and to expand the application of urban green spaces in the design and construction process. Overall, this study aims to explore experts' perceptions on the PM reduction effects of urban green areas. To do this, Q-methodology is employed, which uses both qualitative and quantitative research methodologies to identify common perspectives on a main topic among various groups of experts.

\section{Literature Review}

Despite policy efforts to improve air quality, great results have not transpired, largely because of the continued increase in urbanization and industrialization. Recently, particulate matter have become a serious social problem. Airborne particulates are defined as a Group 1 carcinogen by the International Agency for Research on Cancer (IARC) and the WHO(World Health Organization) [30]. PM concentration is not only an indicator of environmental pollution, but also a factor that directly affects citizens' lives. Because of PM, 90\% of South Koreans have reported feeling uncomfortable in their daily lives, which results in the deterioration of health and limited outdoor activities [13]. Also, the deterioration of indoor air quality, as well as in open spaces, causes various health problems. Therefore, some research has explored the relationships between indoor and outdoor PM concentration within locations such as university facilities and schools [31-33]. Because of the health threat from particulates, most countries have employed legal guidelines both for the tolerable level of emissions from certain kinds of pollution sources and for particulate concentration levels [30,34]. Thus, state and local governments are promoting various policies to reduce PM, and academia and industry are continuously conducting research and development to develop new PM reduction technologies. Nevertheless, such strategies have yet to be supported and applied through clear and comprehensive plans, as there are currently too many suggested methods, such as rules in vehicle emissions, industrial sector regulations, etc.

On the other hand, there is growing concern that PM concentrations are predominantly high in urban areas where the atmosphere is stagnant as a result of heat islands $[9,16,25,26]$. As many citizens live in the city, reducing particles in urban areas has emerged as an important task; to address this, various measures are being conducted, including the relocation of pollutant sources such as factories, the dissemination of eco-friendly vehicles, and restrictions on the operation of old diesel vehicles. Additionally, as green areas are known to contribute to the mitigation of weather changes and air pollution caused by urbanization, expectations for the positive effects from expanding urban green areas are increasing. Attempts to manage PM concentrations by creating green spaces within urban 
areas are evaluated as effective policy when it is not easy to fundamentally control the occurrence of pollution.

Since PM concentration levels have become a more serious issue with regard to its effects on human health, economic productivity, etc., several investigations have been conducted with the aim of decreasing the PM concentration levels [5,14-16]. Research has shown that not only do trees absorb and purify atmospheric pollutants through metabolic processes such as photosynthesis, but they also release beneficial substances from their pores [35]. Several investigations have been conducted on the decontamination of particulate pollution in the ambient air through the allotment of urban forests or green spaces [6]. It has also been found that green spaces in urban areas contribute to mitigating heat island phenomena and to improving air quality by decreasing air temperature [24]. There has also been a number of efforts to reduce particles by using buffered greenery such as roadside green buffer zones $[6,20,21]$. As urban green areas are considered the lung of a city $[11,21]$, planting trees and creating green spaces are realistic ways to reduce air pollution. A study using hourly weather monitoring data in a highly contaminated area discovered that a canopy of urban trees could be used as a realistic method to reduce air pollution [2]. Relatedly, various research on PM adsorption and abatement efficiency by species have been conducted [15,17-19]. In one such study in Vienna, air pollution concentrations were examined for their relationship with the foliage and leaf tissue of urban trees [17]; it was showed that the contaminant concentrations, such as manganese and strontium levels, of leaves in urban areas were significantly higher. Moreover, the LULC (Land cover and land use) of urban areas significantly affected the elemental concentrations in deposited PM on leaves. Some research has involved planting types and spatial structures of urban forests and green spaces to decrease the concentration level of particles [6,24-27]. There have also been many studies on methods used to reduce particle concentration levels using greening techniques such as indoor landscaping, rooftop greening, and wall greening [22,23].

Research on the selection of species and planting techniques to reduce particles has recently expanded, but there remains a lack of specific guidelines or accumulated data on the issue. Furthermore, much concern surrounds the extent to which experts are consistently aware of the particle reduction effect of urban green spaces. As experts have a decisive influence on construction processes and outcomes as well as on theoretical reinforcements and technological advances in related fields, their perception regarding the potential of green spaces to reduce PM is particularly important in the policy process. That is, if experts' level of expectation for green spaces to support particulate matter reduction is low, expectation for the practical incorporation of green spaces would likely be low. Similarly, if policy makers are skeptical about the reduction of particles in urban green spaces, they may be less likely to consider the ecological functions of urban green spaces in response to immediate limitations such as budgets, management needs, and maintenance requirements. Furthermore, even if experts are aware of the effect of urban green areas in reducing particles, at the policy-making stage, it is difficult to demonstrate the theoretically expected results when there is a lack of consensus among field experts in the design and construction stages. Thus, to substantially reduce PM levels through urban green spaces, establishing and promoting relevant policies as well as strengthening the awareness of experts is urgently needed. As particle reduction through urban green spaces receives attention, it is necessary to evaluate how experts' perceptions are formed surrounding urban green spaces and their integration. Through the analysis of the perceptions of experts who establish and implement policies, the potential for urban green spaces to be integrated and thus contribute to reduced PM may thus be improved. Therefore, this study applies Q-methodology to categorize the perception of experts and identify future research and policy directions regarding the effects of particle reduction in urban green spaces. 


\section{Materials and Methods}

\subsection{Q-Methodology}

In this study, Q-methodology is applied to categorize experts' perceptions of urban green spaces and PM. Q-methodology was developed by psychologist William Stephenson in 1935 and is generally used as a technique to explore the subjective types of perception of an issue or object [36,37]. It is a way of quantifying qualitative content by applying statistical concepts; it is generally introduced to understand the process through which a phenomenon occurs [38]. Through Q-methodology, groupings of people with similar thoughts, attitudes, and values can be ascertained, and the differences and commonalities between the groups analyzed [39].

Q-methodology has been widely used in the fields of journalism, education, medical science, and political science. Recently, Q-methodology has been applied in various ways as a method for policy preparation in environmental fields $[40,41]$. In particular, conclusions drawn through Q-methodology can inform environmental policy-making by analyzing the ways in which different groups perceive environmental issues [37,42]. The output derived from Q-methodology can be understood as subjective perception, cognitive structure, schema, etc. formed in relation to the considered topic or subject. It is reasonable to accept the results of $\mathrm{Q}$-methodology as a hypotheses or criteria in terms of the considered perception-developing process, rather than as generalized results; the results of Q-methodology can be considered a starting point for solving a particular problem. In the process of understanding the perception type, as derived from the result of Q-methodology, it is possible to derive the object, procedures, and methods that may solve the problem.

\subsection{Development of the Q-Sample}

The process of research using Q-methodology is based on respondents' evaluation of the basic statements (Q-sample) related to the research topic. The provided statements are the basic variables for typifying the cognitive structure, wherein it is important to search and collect various opinions, attitudes, and valuations related to the subject. Here, Q-samples on urban green areas and PM were collected through literature reviews such as theoretical discussions, media reports, and policy data. Then, 34 statements that reflect the variety of opinions collected in the literature review were selected through brainstorming (Table 1).

Table 1. Statements in the Q-set.

1. The importance of the ecological function of urban green areas will gradually increase.

2. The particle reduction effect of urban green areas is somewhat exaggerated.

3. Environmental pollution abatement through the integration of urban green spaces will only be possible in certain areas.

4. Reduction of particles through urban green areas lowers the rate of occurrence or progression of related diseases.

5. The functions and characteristics of urban green spaces depend entirely on the budget scale.

6. When creating urban green spaces, various aspects should be considered, including ecological aspects.

7. Breakthrough research on the design and construction of urban green spaces to reduce PM is necessary.

8. Further studies on PM reducing tree species and securing the tree species list is needed.

9. Research on the reduction effect of PM by greening techniques, such as green roofs and green walls, is necessary. 
Table 1. Cont.

10. Development of specific planting guidelines for PM reduction is necessary.

11. There is a lack of cooperation between research areas on the effect of PM reduction of green areas.

12. Issues about urban green areas and PM reduction will not last long.

13. To reduce PM, it is of urgent necessity to increase the area of urban green spaces.

14. There is insufficient investment in research on the PM reduction effects of green areas.

15. Urban green spaces should be preferentially placed in areas in which citizens live.

16. It is necessary to make planting methods, such as planting structures for reducing PM, mandatory according to policies and regulations.

17. When constructing urban green areas, planting structure designs and selections of tree species are being systematically conducted.

18. There is a difference in the position of government, academia, and industry in discussions surrounding urban green areas and PM.

19. There are few PM reduction effects caused by the spatial structure of green spaces, such as in a wind corridor.

20. It is better to provide masks to vulnerable groups than to create green spaces in urban areas.

21. There is insufficient government awareness regarding the importance of urban green areas in relation to measures for reducing $\mathrm{PM}$

22. Empirical monitoring data are needed to improve the PM reduction effect of green areas.

23. The creation of green spaces as buffers in pollutant discharging areas, such as industrial zones, should be prioritized.

24. Only some groups benefit from urban green spaces, even in the same area.

25. Given the trend of urbanization, the urban green area rate of the Republic of Korea is not low

26. There is intervention from political interests in PM reduction measures.

27. The creation of urban green area for reducing PM should be led by local governments.

28. There are forces linking urban green areas with PM reduction for commercial purposes.

29. To reduce PM, management of roadside green areas is more important than that of urban forests or parks.

30. Only a few specialized companies can effectively design and construct green areas

31. The urban green space policies of state and local governments are being enforced just for show.

32. Citizens' understanding of the PM reduction effects of urban green areas is lacking.

33. Reduction of primary pollutants such as sulfur dioxide is more urgent than PM reduction.

34. It is more important to manage existing urban green areas than to create new urban green areas. 


\subsection{Data Collection}

In the Q-analysis, the appropriate size of survey participants (P-sample) is commonly claimed to be approximately 40-60 people [43]. Therefore, a total of 57 expert opinions were collected and analyzed in this study.

P-sets should be comprised of different and well-formed opinions that cover a wide variety of views and represent the breadth of opinions in the target population being studied $[36,44]$. Therefore, here, the P-sample consists of 11 officials from government and public institutions, 13 researchers from university and research institutes, and 33 workers from landscape architecture design and construction companies (Table 2).

Table 2. P-sample of participants involved in the survey.

\begin{tabular}{|c|c|c|c|}
\hline & $\begin{array}{l}\text { Division } \\
\text { Total }\end{array}$ & $\begin{array}{c}\mathbf{n} \\
(57)\end{array}$ & $\begin{array}{c}\text { Frequency }(\%) \\
100.0\end{array}$ \\
\hline \multirow{2}{*}{ Gender } & Male & (35) & 61.4 \\
\hline & Female & (22) & 38.6 \\
\hline \multirow{4}{*}{ Age } & $20 \mathrm{~s}$ & (13) & 22.8 \\
\hline & $30 \mathrm{~s}$ & (17) & 29.8 \\
\hline & $40 \mathrm{~s}$ & (19) & 33.3 \\
\hline & 50 s and over & $(8)$ & 14.0 \\
\hline \multirow{3}{*}{ Occupation } & $\begin{array}{l}\text { Government and Public } \\
\text { Institutions }\end{array}$ & (11) & 19.3 \\
\hline & $\begin{array}{c}\text { Universities and Research } \\
\text { Institutes }\end{array}$ & (13) & 22.8 \\
\hline & Enterprise & (33) & 57.9 \\
\hline \multirow{6}{*}{$\begin{array}{l}\text { Major subject area of } \\
\text { interest }\end{array}$} & Environmental Science & (11) & 19.3 \\
\hline & Architecture & (1) & 1.8 \\
\hline & Landscape Architecture & (38) & 66.7 \\
\hline & Forestry & (3) & 5.3 \\
\hline & Policy and Public Administration & (2) & 3.5 \\
\hline & Other & (2) & 3.5 \\
\hline \multirow{5}{*}{ Tour } & 5 years or less & (18) & 31.6 \\
\hline & 6 to 10 years & (10) & 17.5 \\
\hline & 11 to 15 years & (10) & 17.5 \\
\hline & 16 to 20 years & $(6)$ & 10.5 \\
\hline & More than 21 years & (13) & 22.8 \\
\hline
\end{tabular}

Participants from the P-sample were given the 34 statements from the Q-set (Table 1). Depending on the degree of agreement with each statement in the Q-sample, ranging from -4 (strongly disagree) to +4 (strongly agree), the respondents responded with the distribution shown in Figure 1. Collected data were analyzed by the QUANL program.

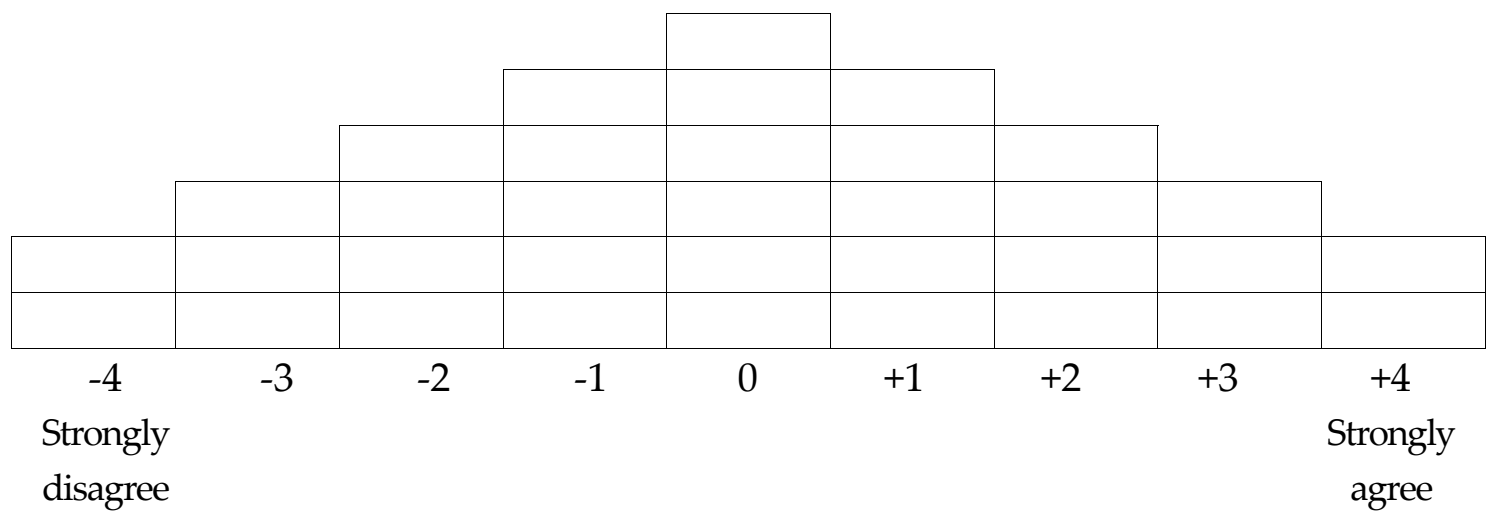

Figure 1. Q-sort form for respondents' agreement with statements presented in the Q-set. 


\section{Results and Discussion}

\subsection{Factor Description}

As a result, experts' perception on urban green spaces and PM was classified into three groups (Table 3). Of the 57 respondents in the survey, 37 belonged to Group 1, nine belonged to Group 2, and 11 to Group 3. The eigenvalue of each group was 15.1095 for 1 group, 3.5988 for 2 groups, and 3.1173 for 3 groups, which were appropriately separated. Variance by group accounted for $26.5 \%$ of Group 1 , $6.3 \%$ of Group 2, and 5.5\% of Group 3; a total of three groups accounted for $38.3 \%$ of the total variance.

Table 3. Eigenvalues and explained variance between groups.

\begin{tabular}{cccc}
\hline & Group 1 & Group 2 & Group 3 \\
\hline Eigenvalue & 15.1095 & 3.5988 & 3.1173 \\
Variance & 0.2651 & 0.0631 & 0.0547 \\
Cumulative & 0.2651 & 0.3282 & 0.3829 \\
Variance & & & \\
\hline
\end{tabular}

The correlations between groups were analyzed as 0.349 for the first and second groups, 0.400 for the first and third groups, and 0.187 for the second and third groups (Table 4). In Q-methodology, the correlation itself is not important, but the correlation coefficient is not so high that it can be interpreted that each group is well differentiated.

Table 4. Correlations between groups of respondents.

\begin{tabular}{lccc}
\hline & Group 1 & Group 2 & Group 3 \\
\hline Group 1 & 1.000 & & \\
Group 2 & 0.349 & 1.000 & \\
Group 3 & 0.400 & 0.187 & 1.000 \\
\hline
\end{tabular}

\subsubsection{Group 1: Active Support Group}

The first group is very positive about the effect of urban green space on the reduction of PM; it is deemed the 'Active support group' and its members support more active policy and research and development (Table 5). Members of Group 1 acknowledge that there is an absolute lack of urban green space and that while other (non-ecological) functions of urban green space are important, they maintain that ecological functions are expected to become more important in the future. Respondents in Group 1 insist that the need exists to develop plant guidelines, develop species lists, study spatial structures, and monitor PM reduction. They also argue that green policy should be strengthened to mandate PM reduction. Additionally, they foresee that the PM issues will not quickly disappear and expect that the reduction of PM through urban green spaces can be a universally applicable and appropriate countermeasure. 
Table 5. Distinguishing statements of Group 1.

\begin{tabular}{|c|c|}
\hline Q-Statement & Z-Score \\
\hline $\begin{array}{l}\text { 1. The importance of the ecological function of urban green areas will } \\
\text { gradually increase. }\end{array}$ & 1.49 \\
\hline $\begin{array}{l}\text { 10. Development of specific planting guidelines for PM reduction } \\
\text { is necessary. }\end{array}$ & 1.36 \\
\hline $\begin{array}{l}\text { 7. Breakthrough research on the design and construction of urban green } \\
\text { spaces to reduce PM is necessary. }\end{array}$ & 1.30 \\
\hline $\begin{array}{l}\text { 15. Urban green spaces should be preferentially placed in areas in which } \\
\text { citizens live. }\end{array}$ & 1.23 \\
\hline $\begin{array}{l}\text { 6. When creating urban green spaces, various aspects should be } \\
\text { considered, including ecological aspects. }\end{array}$ & 1.18 \\
\hline $\begin{array}{l}\text { 16. It is necessary to make planting methods, such as planting structures } \\
\text { for reducing PM mandatory according to policies and regulations. }\end{array}$ & 1.08 \\
\hline $\begin{array}{l}\text { 22. Empirical monitoring data are needed to improve the PM reduction } \\
\text { effect of green areas. }\end{array}$ & 1.07 \\
\hline $\begin{array}{l}\text { 8. Further studies on PM reducing tree species and securing the tree } \\
\text { species list is needed. }\end{array}$ & 1.01 \\
\hline $\begin{array}{l}\text { 2. The PM reduction effect of urban green areas is } \\
\text { somewhat exaggerated. }\end{array}$ & -1.10 \\
\hline $\begin{array}{l}\text { 3. Environmental pollution abatement through the integration of urban } \\
\text { green spaces will only be possible in certain areas. }\end{array}$ & -1.27 \\
\hline $\begin{array}{l}\text { 25. Given the trend of urbanization, the urban green area rate of the } \\
\text { Republic of Korea is not low. }\end{array}$ & -1.29 \\
\hline $\begin{array}{l}\text { 19. There are few PM reduction effects by the spatial structure of green } \\
\text { spaces such, as in a wind corridor. }\end{array}$ & -1.30 \\
\hline $\begin{array}{l}\text { 30. Only a few specialized companies can effectively design and } \\
\text { construct green areas. }\end{array}$ & -1.63 \\
\hline $\begin{array}{l}\text { 20. It is better to provide masks to vulnerable groups than to create } \\
\text { green spaces in urban areas. }\end{array}$ & -1.81 \\
\hline 12. Issues about urban green areas and PM reduction will not last long. & -1.83 \\
\hline
\end{tabular}

In particular, what distinguishes Group 1 from other groups is that there is absolute confidence regarding the effectiveness of urban green areas in reducing PM. They emphasize that the effect of reducing PM in urban green spaces is not exaggerated, and that green spaces have a positive effect on the occurrence and progression of related diseases.

They assert that the ratio of urban green space to all urban space in South Korea is absolutely low, suggesting a high possibility for PM to become a more serious threat in the future, separate from the generation of primary pollutants. Therefore, experts in Group 1 maintain that the development of specific planting plans and the systematic and universal expansion of related technologies are important.

Among the total 57 respondents, there were 37 experts in Group 1, wherein many of the respondents had a positive understanding of the reduction of PM in urban green spaces. In detail, Group 1 included government agencies involved in policy making, universities in related research, and enterprise workers in design and construction. Thus, the expectation level for the PM reduction effect of urban green spaces within Group 1 is high, and future prospects are forming relatively positively across various fields (Table 6). 
Table 6. Group 1 items and Z-scores greater or less than corresponding array Z-scores.

\begin{tabular}{|c|c|c|c|}
\hline Q-Statement & Z-Score & Average & Difference \\
\hline $\begin{array}{l}\text { 10. Development of specific planting guidelines for } \\
\text { PM reduction is necessary. }\end{array}$ & 1.359 & 0.120 & 1.238 \\
\hline $\begin{array}{l}\text { 1. The importance of the ecological function of urban } \\
\text { green areas will gradually increase. }\end{array}$ & 1.487 & 0.285 & 1.203 \\
\hline $\begin{array}{l}\text { 4. Reduction of PM through urban green areas } \\
\text { lowers the rate of occurrence or progression of } \\
\text { related diseases. }\end{array}$ & 0.669 & -0.416 & 1.085 \\
\hline $\begin{array}{l}\text { 25. Given the trend of urbanization, the urban green } \\
\text { area rate of the Republic of Korea is not low. }\end{array}$ & -1.287 & 0.058 & -1.345 \\
\hline $\begin{array}{l}34 . \text { It is more important to manage existing green } \\
\text { areas than to create new urban green areas. }\end{array}$ & 0.540 & 2.067 & -1.527 \\
\hline $\begin{array}{l}\text { 30. Only a few specialized companies can effectively } \\
\text { design and construct green areas. }\end{array}$ & -1.633 & -0.084 & -1.549 \\
\hline $\begin{array}{l}\text { 33. Reduction of primary pollutants such as sulfur } \\
\text { dioxide is more urgent than PM reduction. }\end{array}$ & -0.817 & 0.836 & -1.652 \\
\hline $\begin{array}{l}\text { 12. Issues about urban green areas and PM reduction } \\
\text { will not last long. }\end{array}$ & -1.828 & 0.156 & -1.983 \\
\hline $\begin{array}{l}\text { 2. The PM reduction effect of urban green areas is } \\
\text { somewhat exaggerated. }\end{array}$ & -1.102 & 1.014 & -2.116 \\
\hline
\end{tabular}

\subsubsection{Group 2: Skeptical Group}

Group 2 was analyzed as the 'skeptical group,' or those with skeptical and reserved attitudes regarding the PM reduction effect of urban green spaces (Table 7). Although members of Group 2 agree with the seriousness of the PM problem and the importance of urban green spaces themselves, they recognize that the effect of reducing PM in urban green space is exaggerated and argue that further scientific and technical reviews should be conducted. They believe it is more urgent to manage primary pollutants rather than separately focusing on PM to mitigate air pollution. Additionally, they believe that urban green spaces shoud not only focus on their ecological purposes, but also on other functions and purposes for citizen use, wherein continuous management of urban green spaces is important. Experts in Group 2 pointed out that the current species and planting structure of urban green spaces are not systematic, suggesting that active interest from not only local governments but also other socio-economic entities is necessary.

Table 7. Distinguishing statements of Group 2.

\begin{tabular}{|c|c|}
\hline Q-Statement & Z-Score \\
\hline $\begin{array}{l}\text { 34. It is more important to manage existing urban green areas than to create } \\
\text { new urban green areas. }\end{array}$ & 2.33 \\
\hline 2. The PM reduction effect of urban green areas is somewhat exaggerated. & 1.81 \\
\hline $\begin{array}{l}\text { 6. When creating urban green spaces, various aspects should be considered, } \\
\text { including ecological aspects. }\end{array}$ & 1.64 \\
\hline $\begin{array}{l}\text { 15. Urban green spaces should be preferentially placed in areas in which } \\
\text { citizens live. }\end{array}$ & 1.50 \\
\hline $\begin{array}{l}\text { 22. Empirical monitoring data are needed to improve the PM reduction effect of } \\
\text { green areas. }\end{array}$ & 1.19 \\
\hline $\begin{array}{l}\text { 33. Reduction of primary pollutants such as sulfur dioxide is more urgent than } \\
\text { PM reduction. }\end{array}$ & 1.14 \\
\hline $\begin{array}{l}\text { 29. To reduce PM, management of roadside green areas is more important than } \\
\text { that of urban forests or parks. }\end{array}$ & -1.05 \\
\hline 12. Issues about urban green areas and PM reduction will not last long. & -1.14 \\
\hline $\begin{array}{l}\text { 28. There are forces linking urban green areas with PM reduction for } \\
\text { commercial purposes. }\end{array}$ & -1.28 \\
\hline $\begin{array}{l}\text { 27. The creation of urban green areas for reducing PM should be led by local } \\
\text { governments. }\end{array}$ & -1.34 \\
\hline $\begin{array}{l}\text { 19. There are few PM reduction effects caused by the spatial structure of green } \\
\text { spaces, such as in a wind corridor. }\end{array}$ & -1.42 \\
\hline $\begin{array}{l}\text { 17. When constructing urban green areas, planting structure designs and } \\
\text { selections of tree species are being systematically conducted. }\end{array}$ & -1.90 \\
\hline
\end{tabular}


In particular, what distinguishes Group 2 from other groups is essentially their hesitant evaluation of the effects of PM reduction through urban green space. They emphasize that the environmental contribution of urban green spaces is not universal, that experts have different views on the PM reduction effects of green spaces, and that the level of understanding of urban green spaces by the general public is not high. They believe that the reduction of PM through urban green space does not guarantee a definite effect on public health, and therefore, unconditionally expanding urban green space is not a solution. Group 2 highlights that the ecological effects of green spaces are limited, and its members are thus passive about the necessity of related research, species list development, and guidelines.

In Group 2, the percentage of university researchers was 55.6\%, higher than that of other groups. University researchers' partial skepticism may be attributed to their familiarity with conducting in-depth research into the related fields and contact with various views regarding the reduction of PM and other functional characteristics of urban green spaces; from these experiences, they may tend to form their own cognitive maps based on scientific and empirical evidence rather than on emotional responses based on the issue flow. Therefore, they insist that more objective evidence or verification should be performed when the empirical results of urban green space and their relationsip to PM is not sufficiently established (Table 8).

Table 8. Group 2 items and Z-scores greater or less than corresponding array Z-scores.

\begin{tabular}{|c|c|c|c|}
\hline Q-Statement & Z-Score & Average & Difference \\
\hline $\begin{array}{l}\text { 2. The PM reduction effect of urban green areas is } \\
\text { somewhat exaggerated. }\end{array}$ & 1.806 & -0.440 & 2.245 \\
\hline $\begin{array}{l}\text { 3. Environmental pollution abatement through the } \\
\text { integration of urban green spaces will only be } \\
\text { possible in certain areas. }\end{array}$ & 0.126 & -1.474 & 1.600 \\
\hline $\begin{array}{l}\text { 6. When creating urban green spaces, various aspects } \\
\text { should be considered, including ecological aspects. }\end{array}$ & 1.636 & 0.293 & 1.344 \\
\hline $\begin{array}{l}\text { 18. There is a difference in the position of } \\
\text { government, academia, and industry in discussions } \\
\text { surrounding urban green areas and PM. }\end{array}$ & 0.116 & -1.201 & 1.317 \\
\hline $\begin{array}{l}\text { 33. Reduction of primary pollutants such as sulfur } \\
\text { dioxide is more urgent than PM reduction. }\end{array}$ & 1.142 & -0.144 & 1.286 \\
\hline $\begin{array}{l}\text { 20. It is better to provide masks to vulnerable groups } \\
\text { than to create green spaces in urban areas. }\end{array}$ & -0.671 & -1.911 & 1.240 \\
\hline $\begin{array}{l}\text { 32. Citizens' understanding of the PM reduction } \\
\text { effects of urban green areas is lacking. }\end{array}$ & 0.496 & -0.711 & 1.207 \\
\hline $\begin{array}{l}\text { 34. It is more important to manage existing urban } \\
\text { green areas than to create new urban green areas. }\end{array}$ & 2.330 & 1.172 & 1.158 \\
\hline $\begin{array}{l}\text { 22. Empirical monitoring data are needed to improve } \\
\text { the PM reduction effect of green areas. } \\
\text { 4. Reduction of PM through urban green areas }\end{array}$ & 1.188 & 0.148 & 1.040 \\
\hline $\begin{array}{l}\text { lowers the rate of occurrence or progression of } \\
\text { related diseases. }\end{array}$ & -0.724 & 0.280 & -1.005 \\
\hline $\begin{array}{l}\text { 14. There is insufficient investment in research on the } \\
\text { PM reduction effects of green areas. }\end{array}$ & -0.044 & 1.084 & -1.127 \\
\hline $\begin{array}{l}\text { 8. Further studies on PM reducing tree species and } \\
\text { securing the tree species list is needed. }\end{array}$ & -0.181 & 0.963 & -1.144 \\
\hline $\begin{array}{l}\text { 13. To reduce PM, it is of urgent necessity to increase } \\
\text { the area of urban green spaces. }\end{array}$ & -0.358 & 0.786 & -1.145 \\
\hline $\begin{array}{l}\text { 7. Breakthrough research on the design and } \\
\text { construction of urban green spaces to reduce PM is } \\
\text { necessary. }\end{array}$ & -0.173 & 1.148 & -1.321 \\
\hline $\begin{array}{l}\text { 27. The creation of urban green area for reducing PM } \\
\text { should be led by local governments. }\end{array}$ & -1.345 & -0.008 & -1.336 \\
\hline $\begin{array}{l}\text { 17. When constructing the urban green areas, } \\
\text { planting structure designs and selections of tree } \\
\text { species are being systematically conducted. }\end{array}$ & -1.902 & -0.199 & -1.703 \\
\hline $\begin{array}{l}\text { 10. Development of specific planting guidelines for } \\
\text { PM reduction is necessary. }\end{array}$ & -0.706 & 1.153 & -1.858 \\
\hline
\end{tabular}




\subsubsection{Group 3: Passive Support Group}

The third group on urban green space and PM could be understood as a 'passive support group'; it recognizes the ecological functions of urban green space as a whole and recognizes that not only urban green space, but also various considerations, are needed for PM reduction(Table 9). Their main concern surrounds reinforcing the ecological function of urban green spaces, including particular attention given to the surroundings of urban green spaces that directly affect citizens. They assert that the government, academia, industry, and the public all agree on urban green spaces and the issue of PM, but that more research is needed to solve PM problems. They insist that not only are studies on urban green area design and construction needed, but also the further development of various green techniques and spatial structures are required for the reduction of PM; Group 3 requires sufficient investment in this regard.

Table 9. Distinguishing statements of Group 3.

\begin{tabular}{lc}
\hline \multicolumn{1}{c}{ Q-Statement } & Z-Score \\
\hline 34. It is more important to manage existing urban green areas than to & 1.80 \\
create new urban green areas. & 1.46 \\
12. Issues about urban green areas and PM reduction will not last long. \\
15. Urban green spaces should be preferentially placed in areas in which \\
citizens live. \\
14. There is insufficient investment in research on the PM reduction \\
effects of green areas. \\
9. Research on the reduction effect of PM by greening techniques, such \\
as green roofs and green walls, is necessary. \\
7. Breakthrough research on the design and construction of urban green \\
spaces to reduce PM is necessary. \\
32. Citizens' understanding of the PM reduction effects of urban green \\
areas is lacking. \\
3. Environmental pollution abatement through the integration of urban \\
green spaces will only be possible in certain areas. \\
20. It is better to provide masks to vulnerable groups than to create \\
green spaces in urban areas. \\
18. There is a difference in the position of government, academia, \\
and industry in discussions surrounding urban green areas and PM. \\
19. There are few PM reduction effects caused by the spatial structure of \\
green spaces, such as in a wind corridor.
\end{tabular}

What distinguishes the passive support group from other groups is that they predict that the issue of urban green spaces and PM reduction will not last long, and that the ecological function of urban green space itself is essential. They believe that the ecological function of urban green spaces is already a shared social expectation, and that more attention should be paid to ways in which it could be improved, in practice. In this regard, they argue that the role of local governments, which are in charge of actually creating green areas in each region, is significant.

Experts in the third group are all government officials and enterpise workers, who can basically agree on the effect of reducing PM through urban green space creation. Most of them are majors in the landscape architecture sector, and they are actively supporting the establishment of plans to strengthen the ecological function of green spaces while expecting the improved functionality of the green area. They also recognize that we should not only focus on reducing PM, but also on increasing the value and utility of urban green spaces in terms of overall ecological improvement (Table 10). 
Table 10. Items and Z-scores greater or less than corresponding array Z-scores.

\begin{tabular}{|c|c|c|c|}
\hline Q-Statement & Z-Score & Average & Difference \\
\hline $\begin{array}{l}\text { 12. Issues about urban green areas and PM } \\
\text { reduction will not last long. }\end{array}$ & 1.457 & -1.486 & 2.943 \\
\hline $\begin{array}{l}\text { 27. The creation of urban green area for reducing } \\
\text { PM should be led by local governments. }\end{array}$ & 0.760 & -1.060 & 1.820 \\
\hline $\begin{array}{l}\text { 17. When constructing urban green areas, } \\
\text { planting structure designs and selections of tree } \\
\text { species are being systematically conducted. }\end{array}$ & 0.043 & -1.171 & 1.214 \\
\hline $\begin{array}{l}\text { 30. Only a few specialized companies can } \\
\text { effectively design and construct green areas. }\end{array}$ & 0.172 & -0.987 & 1.159 \\
\hline $\begin{array}{l}\text { 32. Citizens' understanding of the PM reduction } \\
\text { effects of urban green areas is lacking. }\end{array}$ & -1.007 & 0.040 & -1.046 \\
\hline $\begin{array}{l}\text { 3. Environmental pollution abatement through } \\
\text { the integration of urban green spaces will only be } \\
\text { possible in certain areas. }\end{array}$ & -1.679 & -0.571 & -1.109 \\
\hline $\begin{array}{l}\text { 1. The importance of the ecological function of } \\
\text { urban green areas will gradually increase. }\end{array}$ & -0.224 & 1.140 & -1.364 \\
\hline $\begin{array}{l}\text { 22. Empirical monitoring data are needed to } \\
\text { improve the PM reduction effect of green areas. } \\
\text { 18. There is a difference in the position of }\end{array}$ & -0.779 & 1.131 & -1.910 \\
\hline $\begin{array}{l}\text { government, academia, and industry in } \\
\text { discussions surrounding urban green areas and } \\
\text { PM. }\end{array}$ & -2.075 & -0.106 & -1.969 \\
\hline $\begin{array}{l}\text { 6. When creating urban green spaces, various } \\
\text { aspects should be considered, including } \\
\text { ecological aspects. }\end{array}$ & -0.592 & 1.407 & -1.999 \\
\hline
\end{tabular}

\subsection{Consistency Analysis}

Experts' positions on urban green space and PM were divided into three groups but for some statements, most experts showed a consistent perception. The consensus statements of the three groups are shown in Table 11.

Table 11. Consensus items and average Z-scores.

\begin{tabular}{lc}
\hline \multicolumn{1}{c}{ Q-Statement } & Z-Score \\
\hline $\begin{array}{l}\text { 15. Urban green spaces should be preferentially placed in areas in which } \\
\text { citizens live. }\end{array}$ & 1.32 \\
$\begin{array}{l}\text { 9. Research on the reduction effect of PM by the greening techniques, } \\
\text { such as green roofs and green walls, is necessary. }\end{array}$ & 0.76 \\
$\begin{array}{l}\text { 11. There is a lack of cooperation between research areas on the effect of } \\
\text { PM reduction of green areas. }\end{array}$ & 0.54 \\
$\begin{array}{l}\text { 16. It is necessary to make planting methods such as planting structure } \\
\text { for reducing PM, mandatory according to policies and regulations. }\end{array}$ & 0.53 \\
$\begin{array}{l}\text { 31. The urban green space policies of state and local governments are } \\
\text { being enforced just for show. }\end{array}$ & 0.38 \\
$\begin{array}{l}\text { 21. There is insufficient government awareness regarding the } \\
\text { importance of urban green areas in relation to measures for } \\
\text { reducing PM. }\end{array}$ & -0.06 \\
$\begin{array}{l}\text { 26. There is intervention from political interests in PM reduction } \\
\text { measures. }\end{array}$ & -0.36 \\
$\begin{array}{l}\text { 5. The functions and characteristics of urban green spaces depend } \\
\text { entirely on the budget scale. }\end{array}$ & -0.41 \\
$\begin{array}{l}\text { 24. Only some groups benefit from urban green spaces, even in the same } \\
\text { area. }\end{array}$ & -0.83 \\
$\begin{array}{l}\text { 19. There are few PM reduction effects caused by the spatial structure of } \\
\text { green spaces, such as in a wind corridor. }\end{array}$ & -1.61 \\
\hline
\end{tabular}

The consensus statements by experts can be divided into three categories: citizen-friendly green areas, the need for relevant research, and systematic policy establishment. First, most experts believe that green space creation should give priority to the area in which many citizens live. Since urban green space is a public good owned by the region and is not intended to benefit only a certain class, citizen-friendly green areas are interpreted as a position to strengthen green space for all citizens. Second, there are common opinions that related research and development should be strengthened 
regarding the reduction of PM through urban green spaces. As a consensus, respondents believe that PM reduction studies are needed according to various green techniques and spatial structures, and that cooperation between research fields should be strengthened; additionally, it is believed that advances in technology could improve PM reduction through urban green spaces. The third common opinion is that urban green space policy should proceed more systematically. Although experts agree on the overall movement of the government and local governments to reduce PM through urban greenery, they point out that such efforts remain passive and formal, emphasizing that this issue is not a matter of political interests or obscure alterior motives. They also demand more efficient policy promotion because the value and utility of urban green spaces do not align with the budget scale.

The perception groups and the characteristics of each group derived from this study can be considered as a schema resulting from the combination of cognitive and emotional responses to the subject for an extended period of time. Therefore, it is natural for each expert or group to have a different perspective. Even in the presence of diverse perceptions, however, the necessity of creating a civic-friendly green space, expansion of related research, and systematization of urban green policy are important issues that should be pursued at the current level (Figure 2).

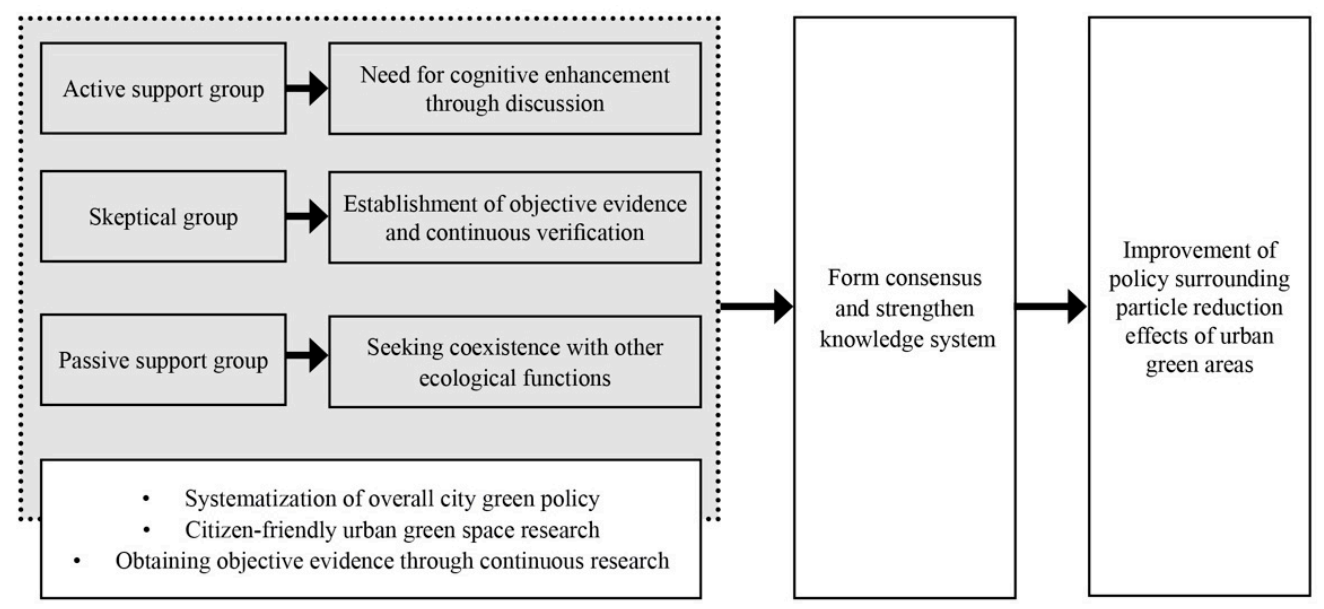

Figure 2. Future countermeasures and development plans by experts' perception classification.

\section{Conclusions}

As the PM reduction effects of urban green spaces and urban forests has been increasingly highlighted, state and local governments have been actively preparing urban green area creation policies to enhance the ecological functions therein. However, due to a lack of sufficient research and empirical data, understanding the perception of experts involved in both the policy-making stage and the design and construction of urban green areas is critical to enhancing the effectiveness of the policy. Therefore, this study aimed to classify experts' perceptions and to ascertain how to form a consensus across several groups, improve awareness, establish policies, and expand the application of such policies in the design and construction process. This ultimately aims to enhance the PM reduction effects of urban green spaces.

As a result of the classification performed herein, experts' perceptions were classified into three categories: an 'active support group', a 'skeptical group', and a 'passive support group'. The 'active support group' emphasizes the need for more proactive policy development, research and development, and field applications while positively assessing the function of urban green space on reducing PM. The 'skeptical group' consists mostly of researchers who believe that more objective and sufficient verification is needed as opposed to excessive expectations for the reduction effect of PM in urban green spaces. Lastly, the 'passive support group' essentially agrees that urban green spaces reduce PM, but asserts that more related research is needed, and suggests that urban green space policies should be strengthened so as to improve the entire ecological function of urban green spaces. As a result, 
experts' opinions on the PM reduction effect of urban green areas are largely in agreement, albeit with some differing ideas surrounding what should be prioritized in urban green spaces as well as what is needed to improve their implementation. In other words, expectations and concerns about the PM reduction function of urban green space coexist. Thus, to further identify what context may contribute to differing attitudes toward green space implementation, further studies on which types of experts are more in agreement with green space implementation and which types are less so are needed. Additionally, empirical evidence accumulated on the reduction effect of PM in urban green areas, including the quantification of particle reduction concentrations in urban green spaces, considerations for policy establishment, design and construction, etc. Furthermore, if the function of the green areas is discussed not only in the context of their effect on particle reduction but also in tandem with other ecological functions, such as mitigation of the heat island effect, doubts from skeptical experts may be resolved. As a result of the study, different types of experts' perceptions were categorized, but there was an overarching consensus on the necessity of creating a citizen-friendly green area, continuous expansion of related research, and efforts to strengthen related policy. These findings may inform the development of a plan needed to reinforce the PM reduction function of urban green areas.

Author Contributions: Study design conceptualization, S.K. and K.A.; Data analysis, S.H.; Supervision, S.-W.L. Funding: This research received no external funding.

Acknowledgments: This paper was supported by Konkuk University in 2016.

Conflicts of Interest: The authors declare no conflict of interest.

\section{References}

1. Janhäll, S. Review on urban vegetation and particle air pollution-Deposition and dispersion. Atmos. Environ. 2015, 105, 130-137. [CrossRef]

2. Nowak, D.J.; Crane, D.E.; Stevens, J.C. Air pollution removal by urban trees and shrubs in the United States. Urban For. Urban Green. 2006, 4, 115-123. [CrossRef]

3. McPherson, E.G.; Simpson, J.R.; Peper, P.J.; Xiao, Q. Benefit-cost analysis of modesto's municipal urban forest. J. Arboric. 1999, 25, 235-248.

4. McPherson, E.G.; Simpson, J.R. Carbon Dioxide Reduction through Urban Forestry: Guidelines for Professional and Volunteer Tree Planters; U.S. Department of Agriculture, Forest Service, Pacific Southwest Research Station: Albany, CA, USA, 1999.

5. Hänninen, O.O.; Palonen, J.; Tuomisto, J.T.; Yli-Tuomi, T.; Seppänen, O.; Jantunen, M.J. Reduction potential of urban PM2.5 mortality risk using modern ventilation systems in buildings. Indoor Air 2005, 15, 246-256. [CrossRef] [PubMed]

6. Kim, S.; Lee, S.; Hwang, K.; An, K. Exploring Sustainable Street Tree Planting Patterns to Be Resistant against Fine Particles (PM2.5). Sustainability 2017, 9, 1709. [CrossRef]

7. Bae, H.-J. Effects of Short-term Exposure to PM10 and PM2.5 on Mortality in Seoul. Korean J. Environ. Health Sci. 2014, 40, 346-354. [CrossRef]

8. Park, E.; Kim, D.; Park, K. Monitoring of ambient particles and heavy metals in a residential area of Seoul, Korea. Environ. Monit. Assess. 2008, 137, 441-449. [CrossRef]

9. Seo, Y.-H.; Ku, M.-S.; Choi, J.-W.; Kim, K.-M.; Kim, S.-M.; Sul, K.-H.; Jo, H.-J.; Kim, S.-J.; Kim, K.-H. Characteristics of PM2.5 Emission and Distribution in a Highly Commercialized Area in Seoul, Korea. J. Korean Soc. Atmos. Environ. 2015, 31, 97-104. [CrossRef]

10. Wilson, A.M.; Salloway, J.C.; Wake, C.P.; Kelly, T. Air pollution and the demand for hospital services: A review. Environ. Int. 2004, 30, 1109-1118. [CrossRef]

11. Chang, C.-C.; Tsai, S.-S.; Ho, S.-C.; Yang, C.-Y. Air pollution and hospital admissions for cardiovascular disease in Taipei, Taiwan. Environ. Res. 2005, 98, 114-119. [CrossRef]

12. Hart, J.E.; Laden, F.; Schenker, M.B.; Garshick, E. Chronic Obstructive Pulmonary Disease Mortality in Diesel-Exposed Railroad Workers. Environ. Health Perspect. 2006, 114, 1013-1017. [CrossRef] [PubMed]

13. Min, J.W. Weekly Economic Review; Treasury Board and Finance: Edmonton, AB, Canada, 2019; pp. 1-12. 
14. Harrison, R.M.; Deacon, A.R.; Jones, M.R.; Appleby, R.S. Sources and processes affecting concentrations of PM10 and PM2. 5 particulate matter in Birmingham (UK). Atmos. Environ. 1997, 31, 4103-4117. [CrossRef]

15. Turpin, B.J.; Lim, H.-J. Species Contributions to PM2.5 Mass Concentrations: Revisiting Common Assumptions for Estimating Organic Mass. Aerosol Sci. Technol. 2001, 35, 602-610. [CrossRef]

16. Zhou, N.; Wang, G.; Zhang, R.; Zhang, L.; Song, Y.; Wu, B.; Li, X.; An, K.; Chu, J. Characterization and Source Apportionment of PM2.5 in an Urban Environment in Beijing. Aerosol Air Qual. Res. 2013, 13, 574-583.

17. Simon, E.; Braun, M.; Vidic, A.; Bogyó, D.; Fábián, I.; Tóthmérész, B. Air pollution assessment based on elemental concentration of leaves tissue and foliage dust along an urbanization gradient in Vienna. Environ. Pollut. 2011, 159, 1229-1233. [CrossRef] [PubMed]

18. Perini, K.; Ottelé, M.; Giulini, S.; Magliocco, A.; Roccotiello, E. Quantification of fine dust deposition on different plant species in a vertical greening system. Ecol. Eng. 2017, 100, 268-276. [CrossRef]

19. Petroff, A.; Mailliat, A.; Amielh, M.; Anselmet, F. Aerosol dry deposition on vegetative canopies. Part I: Review of present knowledge. Atmos. Environ. 2008, 42, 3625-3653. [CrossRef]

20. Kim, J.-H.; Oh, D.-K.; Yoon, Y.-H. Evaluation of Noise Decreasing Effects by Structures in Roadside Buffer Green. J. Environ. Sci. Int. 2015, 24, 647-655. [CrossRef]

21. Yang, G.-S. The Influence of Resident Satisfaction Regarding Buffer Green Space at Meoyng-ji Multi-family Housing in Busan Metropolitan City. J. Korean Inst. Landsc. Archit. 2013, 41, 38-45. [CrossRef]

22. Ottelé, M.; van Bohemen, H.D.; Fraaij, A.L.A. Quantifying the deposition of particulate matter on climber vegetation on living walls. Ecol. Eng. 2010, 36, 154-162. [CrossRef]

23. Rowntree, R.A.; Nowak, D.J. Quantifying the role of urban forests in removing atmospheric carbon dioxide. J. Arboric. 1991, 17, 269-275.

24. Xu, X.; Kim, J.-O. Planting Design Strategies and Green Space Planning to Mitigate Respirable Particulate Matters-Case Studies in Beijing. J. Korean Inst. Landsc. Archit. 2017, 45, 40-49.

25. Ross, Z.; Jerrett, M.; Ito, K.; Tempalski, B.; Thurston, G. A land use regression for predicting fine particulate matter concentrations in the New York City region. Atmos. Environ. 2007, 41, 2255-2269. [CrossRef]

26. Hoek, G.; Beelen, R.; de Hoogh, K.; Vienneau, D.; Gulliver, J.; Fischer, P.; Briggs, D. A review of land-use regression models to assess spatial variation of outdoor air pollution. Atmos. Environ. 2008, 42, 7561-7578. [CrossRef]

27. McDonald, A.G.; Bealey, W.J.; Fowler, D.; Dragosits, U.; Skiba, U.; Smith, R.I.; Donovan, R.G.; Brett, H.E.; Hewitt, C.N.; Nemitz, E. Quantifying the effect of urban tree planting on concentrations and depositions of PM10 in two UK conurbations. Atmos. Environ. 2007, 41, 8455-8467. [CrossRef]

28. Mohapatra, K.; Biswal, S.K. Effect of particulate matter (PM) on plants, climate, ecosystem and human health. Int. J. Adv. Technol. Eng. Sci. 2014, 2, 2348-7550.

29. Andersson-Sköld, Y.; Thorsson, S.; Rayner, D.; Lindberg, F.; Janhäll, S.; Jonsson, A.; Moback, U.; Bergman, R.; Granberg, M. An integrated method for assessing climate-related risks and adaptation alternatives in urban areas. Clim. Risk Manag. 2015, 7, 31-50. [CrossRef]

30. Hamra, G.B.; Guha, N.; Cohen, A.; Laden, F.; Raaschou-Nielsen, O.; Samet, J.M.; Vineis, P.; Forastiere, F.; Saldiva, P.; Yorifuji, T.; et al. Outdoor Particulate Matter Exposure and Lung Cancer: A Systematic Review and Meta-Analysis. Environ. Health Perspect. 2014, 122, 906-911. [CrossRef] [PubMed]

31. Fromme, H.; Diemer, J.; Dietrich, S.; Cyrys, J.; Heinrich, J.; Lang, W.; Kiranoglu, M.; Twardella, D. Chemical and morphological properties of particulate matter (PM10, PM2.5) in school classrooms and outdoor air. Atmos. Environ. 2008, 42, 6597-6605. [CrossRef]

32. de Gennaro, G.; Dambruoso, P.R.; Loiotile, A.D.; Di Gilio, A.; Giungato, P.; Tutino, M.; Marzocca, A.; Mazzone, A.; Palmisani, J.; Porcelli, F. Indoor air quality in schools. Environ. Chem. Lett. 2014, 12, 467-482. [CrossRef]

33. Gemenetzis, P.; Moussas, P.; Arditsoglou, A.; Samara, C. Mass concentration and elemental composition of indoor PM2.5 and PM10 in University rooms in Thessaloniki, northern Greece. Atmos. Environ. 2006, 40, 3195-3206. [CrossRef]

34. Raaschou-Nielsen, O.; Andersen, Z.J.; Beelen, R.; Samoli, E.; Stafoggia, M.; Weinmayr, G.; Hoffmann, B.; Fischer, P.; Nieuwenhuijsen, M.J.; Brunekreef, B.; et al. Air pollution and lung cancer incidence in 17 European cohorts: Prospective analyses from the European Study of Cohorts for Air Pollution Effects (ESCAPE). Lancet Oncol. 2013, 14, 813-822. [CrossRef] 
35. Ju, H.S.; Kim, S.C.; Choi, S.S.; Bae, S.Y. Impacts of Green Spaces on Air Quality; Korea Environment Institute: Sejong, Korea, 2005; p. 132.

36. Jia, H.; Appolloni, A.; Wang, Y. Green Travel: Exploring the Characteristics and Behavior Transformation of Urban Residents in China. Sustainability 2017, 9, 1043. [CrossRef]

37. Qu, Y.; Li, M.; Jia, H.; Guo, L. Developing More Insights on Sustainable Consumption in China Based on Q Methodology. Sustainability 2015, 7, 14211-14229. [CrossRef]

38. Kim, H.K. Q Methodology: Scientific Philosophy, Theory, Analysis and Apploication; Communication Books: Seoul, Korea, 2008.

39. Choi, H.-C. Social Statistics Methodology; Nanam: Seoul, Korea, 2007.

40. Ha, M.J.; Seo, I.S.; Kwon, G.H. Inquiry into the Future Air Pollution in Seoul City and Policy Analysis via the Q methodology. Korea Local Adm. Rev. 2010, 24, 251-272.

41. Choi, C.I.; Jung, J.R. Q-method on the Environmental Conflicts over the Construction of a Gold Course. J. Korean Reg. Dev. Assoc. 2009, 21, 253-272.

42. Barry, J.; Proops, J. Seeking sustainability discourses with Q methodology. Ecol. Econ. 1999, 28, 337-345. [CrossRef]

43. Kim, H.S.; Won, Y.M. Q Methodology; Kyoyookbook: Seoul, Korea, 2000.

44. Webler, T.; Danielson, S.; Tuler, S. Using Q Method to Reveal Social Perspectives in Environmental Research; Social and Environmental Research Institute: Greenfield, MA, USA, 2009.

(C) 2019 by the authors. Licensee MDPI, Basel, Switzerland. This article is an open access article distributed under the terms and conditions of the Creative Commons Attribution (CC BY) license (http://creativecommons.org/licenses/by/4.0/). 